Proceedings

\title{
Small CoM Municipalities and local climate-change responsive strategies
}

Luigi Santopietro1, * and Francesco Scorza ${ }^{2}$

1 Laboratory of Urban and Regional Systems Engineering (LISUT), School of Engineering, University of Basilicata, Viale dell' Ateneo Lucano 10, 85100, Potenza, Italy; luigi.santopietro@unibas.it

2 Laboratory of Urban and Regional Systems Engineering (LISUT), School of Engineering, University of Basilicata, Viale dell'Ateneo Lucano 10, 85100, Potenza, Italy; francesco.scorza@unibas.it

* Correspondence: luigi.santopietro@unibas.it; Tel.: +39-346-515-6120

\begin{abstract}
The Covenant of Mayors (CoM) launched in 2008, is a voluntary initiative supporting the development of energy efficiency and climate-change responsive strategies, oriented to the achievement of the EU climate neutrality by 2050. Every CoM Signatory outlines its commitments into practical measures and projects by a Sustainable Energy and Climate Action Plan (SECAP). Among these measures, good practices (successful examples) developed by Signatories, have been selected as effective results of their interventions. The work focuses on the CoM Small Municipalities, highlighting the main features from their SECAPs and good practices, and selecting the suitable ones for the case study proposed of Castelsaraceno Municipality.
\end{abstract}

Keywords: SECAP, Covenant of Mayors, voluntary-based planning, small Municipalities, European policies

Citation: Santopietro L.; Scorza, F., 2022, Small CoM Municipalities and local climate-change responsive strategies SUPTM 2022 conference proceedings sciforum-053925. https://doi.org/10.31428/10317/10487

Publisher's Note: UPCT and Sciforum stays neutral with regard to jurisdictional claims in published maps and institutional affiliations.

Copyright: () 2022 by the authors. Submitted for possible open access publication under the terms and conditions of the Creative Commons Attribution (CC BY) license (https://creativecommons.org/license s/by/4.0/).

\section{Introduction}

Since 1992, European Cities have begun to adopt local climate strategies with an increasing and positive trend [1], supported by transnational municipal networks (The Climate Alliance, Cities for Climate Protection, Energy Cities, and C40) focusing on the learning process related to climate - change strategies. These networks were joined mainly by large cities, in order to decrease GHG emissions and develop local interventions facing climate-change. Among these city-networks, the voluntary initiative of CoM in October 2021 has gathered 10,752 Signatories from EU and non-EU Countries, where the 67\% of the CoM Signatories have a population under 10,000 inhabitants (the so called XS Municipalities), representing the increasing demand in achieving the EU climate neutrality, supported more from "small" Municipalities than "bigger".

In this scenario, SECAPs can be intended as the overcoming of the institutional instruments (i.e., urban planning regulations, operational plans and programs established by National policies), in providing funds for ordinary interventions in urban areas. As matter of fact, these voluntary plans have developed in total over 21327 actions (19192 mitigation actions and 2135 adaptation actions) from the CoM launch in 2008. Among these actions, everyone CoM Signatory has selected and shared some good practices as fruitful models for the CoM Community to be replicate in every own context. The research after the explanation of the methodology applied (section 2), in section 3 explains the main results achieved in term of statistics from XS CoM and good practices. In Section 4 the authors have chosen among the good practices, some suitable for the small XS CoM Municipality Castelsaraceno, that it is currently developing its SECAP. In section 5 have highlighted the main conclusions and the further developments of this research. 


\section{Methodology}

CoM website represents the main database investigated for this research, considering specifically two directories of the section "Plans \& Actions": "Actions plans" and "Good practices". From the section "Action Plans ", Signatories have been classified per population size according to $\mathrm{CoM}$ classification, Country of origin and $\mathrm{CO}_{2}$ emissions target reduction set. Additionally, they have been considered the occurrences of the Action Plans sectors, in order to understand what is/are main orientations of the planned actions. Instead, from the section "Good practices", the practices have been classified per typology of action (mitigation or adaptation) and per topics, because of the incomplete classification per sector of the actions. Among these "good practices" have selected those developed by Municipalities with a similar population size of Castelsaraceno Municipality (1274 inhabitants) in order to define the most appropriate actions and measures feasible for that context.

\section{Results from methodology: XS CoM and good practices statistics}

Investigating data from $\mathrm{CoM}$ database, the first Country per number of XS Signatories with SECAPs submitted is Italy (2507), followed by the Spain (1455) and the Belgium (101). The remaining 282 XS Signatories have distributed 28 countries EU and not $\mathrm{EU}$, with a mean percentage under the $1 \%$. Considering the commitment in terms of reduction of $\mathrm{CO}_{2}$ emissions, the $69 \%$ of XS Signatories have set a $\mathrm{CO}_{2}$ target in the range $20-30 \%$, close to the $20 \% 2020$ target fixed by the CoM. Only the $31 \%$ of the Signatories have set a more ambitious target over the $30 \%$. Another interesting feature, useful to understand the interventions planning by the XS Signatories, is the selection of the CoM standard sectors concerning environmental, social and urban topics, for their Action Plans. Thus, in table 1 are proposed the XS Signatories sectors occurrences among the Action Plans submitted, considering the count of them and the relative percentage on the total XS CoM Signatories.

Table 1. Occurrences of sectors of CoM Signatories Action

\begin{tabular}{ccc}
\hline Action Plan Sector & $\begin{array}{c}\text { Occurrence of sector on total XS } \\
\text { CoM Signatories }\end{array}$ & $\begin{array}{c}\text { Percentage of sector on total XS } \\
\text { CoM Signatories }\end{array}$ \\
\hline Agriculture & 966 & 22 \\
\hline Industry & 722 & 17 \\
\hline Local electricity production & 3099 & 72 \\
\hline Local heat cold production & 840 & 19 \\
\hline Municipal buildings equipment facilities & 2940 & 68 \\
\hline Others & 1389 & 32 \\
\hline Public lighting & 3482 & 81 \\
\hline Residential buildings & 3370 & 78 \\
\hline Tertiary buildings equipment facilities & 2045 & 47 \\
\hline Transport & 3260 & 76 \\
\hline
\end{tabular}

The last feature evaluated are the good practices provided from 4761 XS Signatories, with a relevant percentage (98\%) of mitigation actions. These good practices are successful examples deriving from the interventions planned in each Action Plan, that can deliver effective results in similar contexts in reaching similar targets and objectives set by the local authorities. On the CoM database, because of the incomplete classification per sector of the actions, the authors suggested a classification per topics close to CoM sector classification (see tab.2). 


\section{Topics}

Categories of intervention

Occurrenc

es on total

Good

Practices

\begin{tabular}{|c|c|c|}
\hline Agriculture & $\begin{array}{l}\text { Transformation of methodologies of agricultural production, Self- } \\
\text { production or Urban agriculture. }\end{array}$ & 428 \\
\hline Environment and Forestry & $\begin{array}{c}\text { Waste management, Optimization of resource consumption, Climate } \\
\text { comfort, Water spaces of environmental value, Conservation- } \\
\text { preservation or protection of land, Regeneration and naturalization of } \\
\text { natural spaces. }\end{array}$ & 173 \\
\hline Buildings & $\begin{array}{c}\text { Improvement of resistance or protection of vulnerable equipment or } \\
\text { housing, reusing obsolete typologies }\end{array}$ & 39 \\
\hline Disaster Risk Reduction & $\begin{array}{l}\text { Security against natural hazards, Resilience, Self-Protection, Creation of } \\
\text { dams, canals, or similar flood protections, Avoid risk areas, Climate or } \\
\text { vulnerability map or climate records, Equality or social protection. }\end{array}$ & 17 \\
\hline Energy Management & $\begin{array}{l}\text { Energy efficiency, improving public buildings energy efficiency or } \\
\text { improving private buildings energy efficiency }\end{array}$ & 3116 \\
\hline Transport and Mobility & $\begin{array}{c}\begin{array}{c}\text { Sustainable mobility: pedestrian and cycle paths, renovation of vehicle } \\
\text { fleet }\end{array} \\
\text {. }\end{array}$ & 547 \\
\hline Urban and Spatial Planning & $\begin{array}{l}\text { Increase or improvement of spaces, strategies for the development of } \\
\text { adaptation/mitigation actions, Optimization of the location of urban } \\
\text { developments, Regeneration and renovation of abandoned areas }\end{array}$ & 87 \\
\hline Water Management & $\begin{array}{l}\text { Security and guarantee of supplies and networks, Efficiency in the use } \\
\text { and management of water, Improvement of storm networks or systems to } \\
\text { prevent flooding, Control and management of groundwater, Spaces or } \\
\text { places to control excessive rainfall and Permeable surfaces. }\end{array}$ & 63 \\
\hline
\end{tabular}

Table 2. Coded data for each "good practice" of the CoM database

\section{Intervention proposals for the design of Castelsaraceno Municipality SECAP}

Castelsaraceno Municipality represents an interesting case study for the XS CoM Municipalities: it is located in an inland area of the South of Italy (Basilicata Region) and the only transport infrastructure of the territory is the road network, thus the $\mathrm{CO}_{2}$ emissions for the transport SECAP sector have to be related only to the vehicle transport.

The Municipality is currently developing its SECAP based on the previous SEAP (Sustainable Energy Action Plan, that characterized the first season of the CoM from 2008 to 2020) and since August 2021, the Municipality has opened the world's longest Tibetan bridge, orienting its own development on tourism. Hence, these aspects represent a boost to evaluate good practices tailored to the Municipality. The authors find three priority topics among the good practices evaluated, where it is possible design interventions: transport and mobility, building and disaster risk reduction. Suitable references from good practices for Castelsaraceno Municipality are:

- Pacs del Penedès, Vilamartin De Valdeorras and Vilminore di Scalve Municipalities, for the renewal of the private car fleet while Arnoia, Roncobello and Abla Municipalities for the support to pedestrian and sustainable mobility;

- Sobrado dos Monxes, El Real de la Jara and Songavazzo Muncipalities for the energy efficiency and restoration of the private households;

- Ribera d'Urgellet Municipality, for the development of the municipal civil protection document plan according to the territorial risks associated with climate change. 


\section{Conclusions}

Analyzing data from CoM database, two main features from XS small CoM Municipalities come out:

1. A widespread success of the voluntary planning trough the SECAPs of the XS CoM Signatories, achieving the energy and climate objectives [2];

2. A widespread occurrence of ordinary interventions on the urban areas supported by the SECAPs instead of institutional instruments (i.e. urban planning regulation, operational plans and programs established by National policies).

Analyzing statistics from XS CoM Municipalities, 80\% of XS Signatories have chosen a $\mathrm{CO}_{2}$ emissions target reduction set within the range $20-30 \%$. This highlights the choice to set targets closer to the $20 \%$ according to the EU 2020 target, rather than targets over $30 \%$ of $\mathrm{CO}_{2}$ reduction. Indeed, only the $12 \%$ of the Signatories have set a more ambitious target over the $30 \%$ according to the current CoM target (i.e. the reduction at least of 30\% of $\mathrm{CO}_{2}$ emissions).

Considering the occurrences of the sectors, "private" sectors (involving not only public actors but also private company, stakeholders etc..), it shows a widespread success of policies related to the improvement of the energy efficiency/production of the buildings. The remarkable number of Action Plans with interventions on transport sector, shows a changing of the idea of mobility oriented towards sustainable ways, fostering the emissions reduction.

In this scenario, previous works [3-5] show that a systemic vision should be preferred to the sector one, in order to achieve an integrated urban vision [6], through a vison of the Municipalities by set of systems (such as green spaces, green infrastructures waterproofed soils, energy system, active mobility etc..).

This new season of urban and territorial planning based on a voluntary participation, is representative of the high demand in implementation of sustainable territorial development objectives. It is also promising that small Municipalities are the main supporter to the roadmap achieving the EU2050 target with their efforts facing climatechange.

Conflicts of Interest: The author declares no conflict of interest.

\section{References}

1. Hakelberg, L. Governance by Diffusion: Transnational Municipal Networks and the Spread of Local Climate Strategies in Europe. Glob. Environ. Polit. 2014, 14, 107-129, doi:10.1162/GLEP_a_00216.

2. Santopietro, L.; Scorza, F. The Italian experience of the covenant of mayors: A territorial evaluation. Sustain. 2021, 13, 1-23, doi:10.3390/su13031289.

3. Santopietro, L.; Faruolo, G.; Scorza, F.; Rossi, A.; Tancredi, M.; Pepe, A.; Giordano, M. Geovisualization for Energy Planning. In Lecture Notes in Computer Science (including subseries Lecture Notes in Artificial Intelligence and Lecture Notes in Bioinformatics); 2020; Vol. 12252 LNCS, pp. 479-487 ISBN 9783030588106.

4. Corrado, S.; Giannini, B.; Santopietro, L.; Oliveto, G.; Scorza, F. Water Management and Municipal Climate Adaptation Plans: A Preliminary Assessment for Flood Risks Management at Urban Scale; 2020; Vol. 12255 LNCS; ISBN 9783030588199.

5. Santopietro, L.; Scorza, F. A Place-Based Approach for the SECAP of Potenza Municipality: The Case of Green Spaces System. In Lecture Notes in Computer Science (including subseries Lecture Notes in Artificial Intelligence and Lecture Notes in Bioinformatics); 2020; Vol. 12255 LNCS, pp. 226-234 ISBN 9783030588199.

6. Scorza, F.; Santopietro, L. A systemic perspective for the Sustainable Energy and Climate Action Plan (SECAP). Eur. Plan. Stud. 2021, 1-21, doi:10.1080/09654313.2021.1954603. 